\title{
Single cell gel electrophoresis as a tool to assess genetic damage in Heleobia cf. australis (Mollusca: Gastropoda) as sentinel for industrial and domestic pollution in Montevideo bay (Uruguay)
}

\author{
Silvia Villar ${ }^{\text {* }}$, Noelia Kandratavicius ${ }^{2 *}$, Stefanie Martinez ${ }^{1}$, Pablo Muniz $^{2 * *}$
}

\author{
${ }^{1}$ Microscopía Electrónica de Barrido, Epifluorescencia y EDS. Laboratorio de Genética Toxicológica. Facultad de Ciencias, UdelaR. \\ ${ }^{2}$ Ocenaografía y Ecología Marina, Instituto de Ecología y Ciencias Ambientales, Facultad de Ciencias, UdelaR \\ (Iguá 4225, Montevideo 11400, Uruguay) \\ *Equal author contribution: villararias@yahoo.com/nkandra@fcien.edu.uy \\ **Corresponding author: pmmaciel@fcien.edu.uy \\ Financial support: Partially CSIC and SNI-ANII.
}

\section{ABstract}

The knowledge of the extent of DNA damage in aquatic organisms in polluted areas is an important issue because contamination may alter their health at sublethal levels. Although molluscs have been widely used to monitor water pollution, there are no records of in vivo genotoxicity studies. Heleobia cf. australis, is distributed in almost all Uruguayan coastal ecosystems, including highly polluted sites. The comet assay is a damage genetic biomarker based on the migration of negatively charged DNA fragments produced by mutagenic agents in individual cells. Live individuals were collected in the Montevideo Bay (impacted area) and Laguna Garzón (control) to analyze the presence of mutagenic agents in the former site through comet assay. Cells from organisms of the impacted area showed significantly higher levels of genetic damage than those obtained in the control population, measured by percentage of DNA in the tail. Although preliminary, this approach supports the idea that $H$. cf. australis could be used as a sentinel to evaluate the presence of mutagenic agents in estuarine environments, alerting to the impact of contamination in its early stages.

Descriptors: Comet assay, Genotoxicity, Gastropods, Pollution, Estuarine system, Río de la Plata.

\section{RESUMO}

O conhecimento dos danos no DNA em organismos aquáticos de áreas poluídas é uma questão importante, já que a contaminação pode vir a alterar os organismos em níveis subletais. Apesar dos moluscos terem sido amplamente utilizados para monitorar a poluição da água, não há registros de estudos in vivo de genotoxicidade. Heleobia cf. australis é um pequeno gastrópode amplamente distribuído em quase todos os ecossistemas costeiros uruguaios, inclusive em locais altamente poluídos. O ensaio do cometa é um biomarcador genético do dano baseado na migração de fragmentos de DNA com carga negativa produzidas por agentes mutagênicos. Foram coletados indivíduos vivos na Baía de Montevidéu (área impactada) e Laguna Garzón (área controle) para analisar a presença de agentes mutagênicos que ocasionassem dano genético. Células de organismos da área impactada apresentaram níveis significativamente mais elevados de danos genéticos do que os obtidos na área controle. Esse nível de dano foi medido pela porcentagem de DNA na cauda. Embora preliminar, esta abordagem apoia a noção de que $H$. cf. australis poderia ser usado como sentinela para avaliar a presença de agentes mutagênicos em ambientes estuarinos, alertando sobre o impacto da poluição em estágios iniciais.

Descritores: Ensaio cometa, Genotoxicidade, Gastrópodes, Poluição, Sistema estuarino, Rio da Prata. 


\section{INTRODUCTION}

In recent years, the ecological integrity of many estuaries and coastal systems has been affected by activities related to human population growth and land use (NIGRO et al., 2006; NEWTON et al., 2012). The Montevideo Bay receives municipal effluents (either the untreated discharges or only primary treated sewage) of approximately 1.5 million people as well as multiple industries including a large thermoelectric center, a major petroleum refinery and an active port (MUNIZ et al., 2002; 2004a, b; 2005; 2011, VENTURINI et al., 2015). At present, recreational activities that involve direct contact with water are not possible in the Montevideo Bay, mainly due to the input of wastes coming from streams and the sewage outlets that drain directly into the bay, however they do still occur as does the consumption of fish caught in the bay.

In polluted areas, the determination of physical and chemical variables by analytic methods has been prioritized historically (LIVINGSTONE et al., 1992). Nevertheless, there are several organisms that can be used as environmental bioindicators (sentinels). The use of biological response to stress (or biomarkers) in sentinel species has become a major issue in environmental quality evaluation and risk assessment (NIGRO et al., 2006). Among the numerous ecotoxicological biomarkers proposed in the last three decades, those based on responses at the molecular and cellular level represent the earliest signals of environmental disturbance and are commonly used for biomonitoring (COLLINS, 2004). The single cell gel electrophoresis (SCGE) or the comet assay is useful to measure DNA damage in eukaryotic cells or disaggregated tissues (CLEMENT et al., 2004; MACHELLA et al., 2006; EMMANOUIL et al., 2007; GRAZEFFE et al., 2008). The comet assay is also a valuable tool in basic research not only to analyze the mutagenic action of compounds but also the process of the repair of DNA (ASKETA and COLLINS, 2013). The assay depends on the relaxation of supercoiled DNA in agarose-embedded nucleoids and the migration of DNA from individual cells exposed to genotoxic agents, which generate an image that resembles a comet; the tail is basically formed by fragments of DNA (COLLINS, 2013). The comet assay has been applied to cells in culture, blood cells taken from animals or humans, haemolymph cells from mollusks and insects, sperm, disaggregated animal tissues, yeast, nuclei released from plant tissue; in fact, any eukaryotic cell type that can be obtained as a single cell or nuclear suspension seems to be amenable to comet assay analysis (COLLINS et al., 2008).

The benthic fauna is an important component of estuaries, playing vital roles in the decomposition of detritus, nutrient cycling and energy. The close association among benthos and substrate could be severely affected by organic and chemical pollutants accumulated in the sediment (HYLAND et al., 2005). Mollusks are classical sentinel organisms, which have been widely used for monitoring marine pollution because they live and feed in these habitats (O'CONNOR, 2002). One of the main reasons for their suitability as sentinels is their ability to accumulate numerous pollutants from their natural environment (HUNG et al., 2001).

The small snail Heleobia cf. australis was chosen for this study because it is a common estuarine organism distributed in almost all Uruguayan coastal ecosystems (MUNIZ et al., 2012; GIMÉNEZ et al., $2005,2014)$ but specially because it is dominant in impacted areas, being the only living organism found in the inner zones of Montevideo Bay (DANULAT et al., 2002; MUNIZ et al., 2011). Several authors have studied gastropods of the family Hydrobiidae, including Hydrobia acuta, Hydrobia ulvae, Hydrobia ventrosa and Heleobia australis, and have demonstrated alterations in population structure and dynamics, life cycle, production, morphology, reproduction and growth in response to biotic and abiotic changes in coastal aquatic ecosystems (GRAZEFFE et al., 2008). All these reasons make $H$. cf. australis appropriate for the determination of the anthropic impact on this ecosystem.

In this study, we analyze for coastal estuarine zones the suitability of Heleobia cf. australis as an environmental sentinel for coastal estuarine zones, to determine whether the organisms from Montevideo Bay respond to the present impact and polluted status. In this regard, the comet assay was adapted to analyze the genetic effects of contaminants in H. cf. australis. The protocol was validated through the in vivo exposure of individuals to increasing concentrations of hydrogen peroxide using individuals from the bay (a highly impacted area) and individuals from Garzón 
Lagoon as controls. To be useful as sentinels, the DNA damage exhibited by organisms needs to be related to the impact level of the site in which they live and both populations have to show similar responses to the action of gentotoxic agents in the validation test.

\section{MATERIAL AND METHODS}

The Montevideo Bay (Figure 1), covering an area of around $12 \mathrm{~km}^{2}$, is part of the Rio de la Plata estuary, between $34^{\circ} 52^{\prime}-34^{\circ} 56^{\prime} \mathrm{S}$ and $56^{\circ} 10^{\prime}-56^{\circ} 15^{\prime} \mathrm{W}$; its water depth reaches $5 \mathrm{~m}$ except in navigation channels (9-11m depth). The Rio de la Plata is a microtidal environment and its hydrodynamics is controlled mainly by wind forcing and river flow (O' CONNOR, 1991; GUERRERO et al., 1997). The sediments are constituted of silt and clay (MUNIZ et al., 2002). The snail samples were taken using a $0.05 \mathrm{~m}^{2}$ van Veen grab in August 2010. Ten samplings were taken in several areas of the inner Montevideo Bay to constitute a composite sample of the animals (Figure 1). Garzón Lagoon's population was used as control because of its low anthropogenic impact (DEFEO et al., 2009, MUNIZ et al., 2012). Also ten replicates were taken to obtain the snails (Figure 1). All the samples were sieved through $0.5 \mathrm{~mm}$ mesh in situ with water from the site and the live individuals were collected and transported to the laboratory in this water. The genotoxic effects were evaluated at molecular level by single cell gel electrophoresis (Comet assay). After dissection, all tissues were macerated due to the extremely small size of this species, (5 $\mathrm{mm}$ average) (CARECEDO and FIORI, 2012) and trypsinizated
(trypsin-EDTA 1X solution, 0.025\%) in Hanks' salt solution ( $\left.\mathrm{HBSS}, \mathrm{GIBCO}^{\circledR}\right)\left(\mathrm{Ca}^{+2}\right.$ and $\mathrm{Mg}^{+2}$ free). After digestion, the enzyme was deactivated by diluting with $4 \mathrm{ml}$ of $0.025 \%$ HBSS solution. The resulting digestion product was recovered by $2.5 \mathrm{ml}$ syringes; the cell suspension was centrifuged at $2000 \mathrm{rpm}$ for 5 min and the pellet used for the Comet assay. Cell viability was evaluated by trypan blue exclusion, using those samples with a survival rate of $90 \%$ or higher. Further, the procedure for the Comet assay was carried out in accordance with WILSON et al. (1998). Slides were stained with propidium iodide (IP) and observed under an Olympus fluorescence microscope (240X). Damaged nuclei became comets due to DNA migration towards the anode. The DNA damage was quantified by Comet Score $^{\mathrm{TM}}$ (USA) software, as the percentage of DNA which migrated into the comet tail (tail DNA) as is suggested by the comet assay interest group (http://www.cometassay. com/). Seventy animals of each site (Montevideo Bay and Garzón Lagoon) were obtained. Ten animals per tube were macerated - covering all the sizes found in each place ( 7 tubes). Two slides per tube were obtained. Fifty nuclei per slide were scored, using nuclei that presented the same size and the same total amount of DNA (KOSMEHL et al., 2008); the mean was calculated for the total nuclei. Before undertaking the comparison between Montevideo Bay and Garzón Lagoon, a validation test using hydrogen peroxide $\left(\mathrm{H}_{2} \mathrm{O}_{2}\right)$ was conducted following RANK and JENSEN (2003) to compare the responses of both populations. Eighty animals from each population were used as follow: the animals were exposed to increasingly concentrated solutions in appropriate water of the mutagen $(0,10$, $50,100 \mu \mathrm{M}$ ) for 15 minutes at $15^{\circ} \mathrm{C}$ (twenty for each

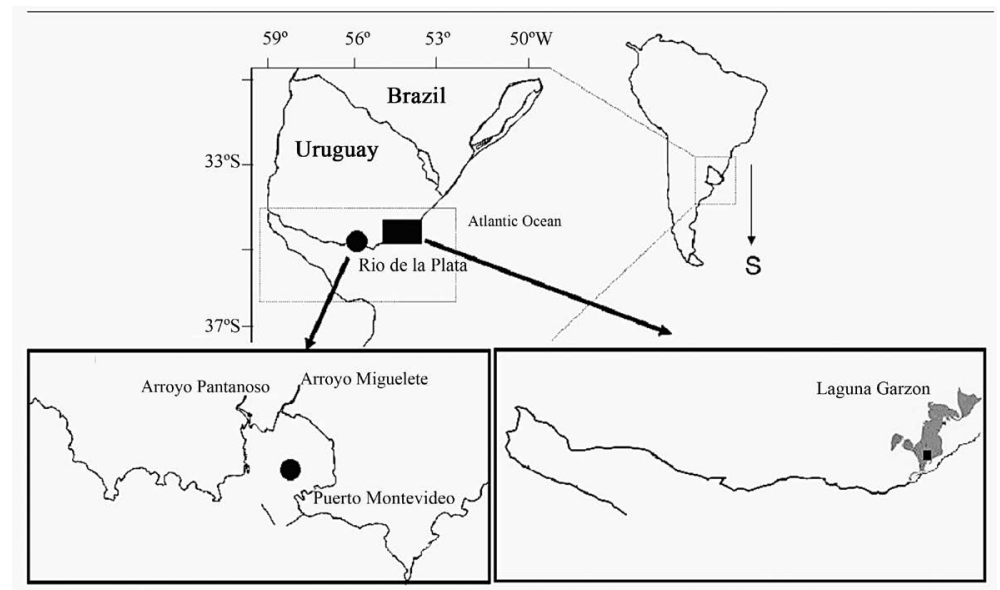

Figure 1. Areas of sample collection (solid circle shows the inner part of the Montevideo Bay and solid square shows Garzón Lagoon). 
concentration) and the comet assay was undertaken under the same conditions as described above. All data were analyzed by parametric statistics (Student's test) after looking at the normalization and homogeneity of variance of the variable (ZAR, 2008).

\section{RESULTS}

The results of the validation assessment for each population are shown in Figure 2. For a $100 \mu \mathrm{M}$ concentration, the cells attained almost the $50 \%$ of DNA damage in both cases (i.e., of animals from Montevideo Bay and Garzón Lagoon). Differences in DNA damage analyzed by single cell electrophoresis were statistically significant between doses for both populations, however both showed similar responses to the action of $\mathrm{H}_{2} \mathrm{O}_{2}$ (they did not show significant differences at $p<0.05$ ) thus showing similar responses to the same genotoxic agent.

The samples of $H$. cf. australis from Montevideo Bay (impacted site) showed levels of DNA damage of around $16.6 \%$ (tail DNA). However, the maximum value registered was $84.4 \%$. The samples from Garzón Lagoon (the control site) showed an average value of $5.6 \%$. The maximum value registered was of $73.1 \%$. In figure 3 it is observed that the DNA damage for Montevideo Bay samples is higher (statistically significant at $p<0.05$ ) than those of Garzón Lagoon, thus indicating a higher impact at the former site.

\section{DISCUSSION}

The study area is located in Montevideo Bay, a semi-enclosed urban bay that receives large amounts

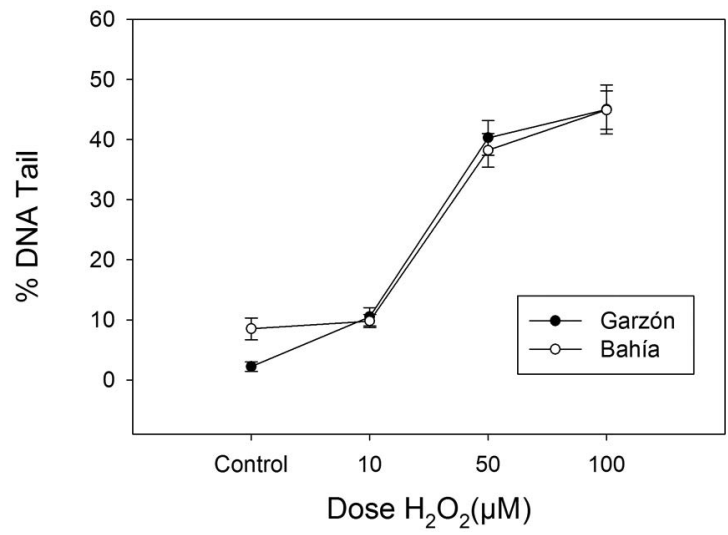

Figure 2. DNA damage levels in response to increasing doses of hydrogen peroxide. Bars indicate SE. of domestic and industrial sewage through the Pantanoso and Miguelete streams and which also contains Montevideo Harbour, the electric plant's water stream and the refinery (MUNIZ et al., 2004a,b). In previous studies, the inner zone of Montevideo Bay presented heterogeneity in its sediment composition, silt being the dominant fraction. This zone presented higher temperatures than the adjacent coastal zone, low salinity, acid bottom waters ( $\mathrm{pH} 5.97)$, a tendency to anoxic conditions by low redox potential $(<200 \mathrm{mV})$

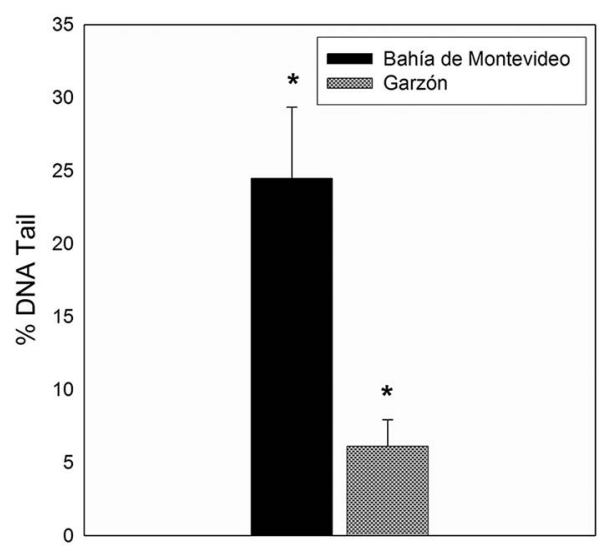

Figure 3. DNA damage per site (Montevideo Bay and Garzón Lagoon) with SE ( $p<0.05 ; \mathrm{n}=70$ per site $)$ * Significant differences between the two sites are shown.

and higher levels of chromium (530.8 $\mathrm{mg} \mathrm{kg}^{-1}$ annual average for the whole inner Bay) and lead (324.1 mg $\mathrm{kg}^{-1}$ annual average for the whole inner Bay) (MUNIZ et al., 2002; MUNIZ et al., 2004b).

Biological responses to environmental pollution are often barely interpretable due to the mixture of pollutants from different sources that can trigger varied responses (ROCHER et al., 2006). Analyze the impact of pollution in estuarine environments is very important, especially at molecular levels where the impact of contaminants could not be detected by traditional tools (diversity index, sizes and morphology analysis, community composition and others). If DNA damage are not repaired they can trigger a cascade of biological consequences at cellular, organ and finally at the population and community level (LEE and STEINERT, 2003).

DNA damage is associated with reduced growth, reduced survival and abnormal development (STEINERT, 1999). The present study assessed the 
genotoxic effects of pollutants in a zone with high levels of anthropogenic activity, using $H$. cf. australis as a sentinel organism, through the comet assay as biomarker for the first time in the literature.

The validation analysis revealed that both populations have similar responses under the effect of the same mutagen and under the same conditions as well as a very clear dose-response effect showing increased DNA damage with increased concentrations of $\mathrm{H}_{2} \mathrm{O}_{2}$.

Several investigations have reported that the trace metals in the marine environment can cause serious disturbance in the physiological status of some species of marine organisms at molecular level with long-term effects on entire communities (TRANNUM et al., 2004; RHEE et al., 2007, 2009; DEASI et al., 2010; SARKAR, 2011). Genotoxic agents such as polycyclic aromatic hydrocarbons (PAHs), persistent organic pollutants (POPs) and heavy metals (KRISHNA KUMARI et al., 2006) cause sublethal damage that tends to accumulate in organisms and generate alterations in communities (WALKER, 2009; SARKAR et al., 1997; SARKAR et al., 1994). SARKAR et al. (2014) demonstrated that the DNA integrity of the gastropod $M$. granulate off the coast of Goa (India) was drastically reduced due to the impact to genotoxic pollutants prevalent at the site, provoked by the extensive tourist activity as well oil spills related to the shipping activity in the proximities.

Montevideo Bay presents high levels of those contaminants and the prevalence in the estuarine ecosystem of these agents is causing damage to the genetic material of H. cf. australis, either directly or indirectly. As a sentinel, our findings indicate that the rest of the biota that integrates the community may be affected at least at molecular level in such a way as to compromise the composition and survival of the aquatic community and the health of the people who fish in this zone.

Our results are below the values $(35.9 \%)$ found by NIGRO et al. (2006) for mussels in the estuary of the River Cecina (Tuscany, Italy) which also exhibits a high level of urbanization and industrial pollution as well as $\mathrm{Cr}, \mathrm{Pb}$ and $\mathrm{Hg}$. However, the values found for their controls (Palmaria Island, $150 \mathrm{~km}$ north of the study area) are higher (26.7\%) than the values for our control zone (5.6\%) (Garzón Lagoon) that is located
$230 \mathrm{~km}$ east of Montevideo Bay. STEINERT et al. $(1998 \mathrm{a}, \mathrm{b})$ found high DNA damage expressed as comet tails in mussels collected at San Diego Bay with high concentrations of metals in somatic and germ cells as compared with those from a nearby reference site. This first approximation supports the contention that $H$. $c f$. australis could be used as a sentinel for the evaluation of the health status of estuarine environments in the early stages of xenobiotic action. Its presence in impacted areas is probably due to several factors such as an efficient DNA repairing system and/or a good detoxification mechanism that calls for demonstration in future investigations.

H. cf. australis could be used as a good model for laboratory testing because these small snails are easy to maintain, need little space and present a good dose-response at molecular level, as the $\mathrm{H}_{2} \mathrm{O}_{2}$ assay demonstrated. Although there are few data on the metabolism, cell cycle and DNA repair processes in invertebrates, it is essential to detect mutagenic effects in these organisms in order to evaluate the impact of pollution in an aquatic ecosystem (JHA, 1998; GRAZEFFE et al., 2008). In this sense, this study makes a useful contribution to knowledge of the subject.

\section{ACKNOWLEDGEMENTS}

This work was partially financed by CSIC (I+D) and ANII, Uruguayan research agencies. Special thanks are due to our colleagues from Oceanografía y Ecología Marina Lab. for their help in the field sampling. PM also thanks SNI-ANII.

\section{REFERENCES}

AZQUETA, A.; COLLINS, A. R. The essential comet assay: a comprehensive guide to measuring DNA damage and repair. Arch. Toxicol., v. 87, n. 6, p. 949-968, 2013.

CARCEDO, M. C.; FIORI, S. M. Long-term study of the life cycle and growth of Heleobia australis (Caenogastropoda, Cochliopidae) in the Bahía Blanca estuary, Argentina. Cienc. Mar, v. 38, n. 4, p. 589-597, 2012.

CLÉMENTE, B.; DEVAUX, A.; PERRODIN, Y.; DANJEAN, M.; GHIDINI-FATUS, M. Assessment of sediment ecotoxicity and genotoxicity in freshwater laboratory microcosms. Ecotoxicology, v. 12, n. 4, p. 323-333, 2004.

COLLINS, A. R. The comet assay for DNA damage and repair: principles, applications, and limitations. Mol. Biotechnol., v. 26, n. 3, p. 249-61, 2004. 
COLLINS, A. R.; AZQUETA, A. A.; BRUNBORG, G.; GAIVAO, I.; GIOVANNELLI, L.; KRUSZEWSKI, M.; SMITH, C. C.; STETINA, R. The comet assay: topical issues. Mutagenesis, v. 23, n. 3, p.143-151, 2008.

COSTANZA, R.; D'ARGE, R.; GROOT, R.; FARBER, S.; GRASSO, M.; HANNON, B.; LIMBURG, K.; NAEEM, S.; O'NEILL, R. V.; PARUELO, J.; RASKIN, R. G.; SUTTON, P.; VAN DEN BELT, P. M. The value of the world's ecosystem services and natural capital. Nature, 387, p. 253-260, 1997.

DANULAT. E.; MUNIZ, P.; GARCÍA-ALONSO, J.; YANNICELLI, B. First assessment of the highly contaminated harbour of Montevideo, Uruguay. Mar. Pollut. Bull., v. 44, n. 6, p. 554-565, 2002.

DEASI. S. R.;VERLECAR, X. N.; ANSARI, Z. A.; JAGTAP, T. G.; SARKAR, A.; DEEPTI, V.; DALAL, S. G. Evaluation of genotoxic responses of Chaetoceros tenuissimus and Skeletone acostatum to water accommodated fraction of petroleum hydrocarbons as biomarker of exposure. Wat. Res., v. 44, n. 7, p. 2235-2244, 2010.

DEFEO, O.; HORTA, S.; CARRANZA, A.; LERCARI, D.; DE ALAVA, A.; GOMEZ, J.; MARTINEZ, G.; LOZOYA, J. P.; CELENTANO, E. Hacia un manejo ecosistémico de las pesquerías. Áreas Marinas Protegidas en Uruguay. Montevideo: Facultad de Ciencias-DINARA, 2009. $122 \mathrm{p}$.

EMMANOUIL, C.; SHEEHAN, T. M. T.; CHIPMANA, J. $\mathrm{K}$. Macromolecule oxidation and DNA repair in mussel (Mytilus edulis L.) gill following exposure to $\mathrm{Cd}$ and $\mathrm{Cr}$ (VI). Aquat. Toxicol., v. 82, n. 1, p. 27-35, 2007.

GIMÉNEZ, L.; BORTHAGARAY, A. I.; RODRÍGUEZ, M.; BRAZEIRO, A.; DIMITRIADIS, K. Scale-dependent patterns of macrofaunal distribution in soft-sediment intertidal habitats along a large-scale estuarine gradient. Helgol. Mar. Res., v. 59, n. 3, p. 224-236, 2005.

GIMÉNEZ, L.; DIMITRIADIS, C.; CARRANZA, A.; BORTHAGARAY, A. I.; RODRÍGUEZ, M. Unravelling the complex structure of a benthic community: A multiscale-multianalytical approach to an estuarine sandflat. Estuar. Coast. Shelf Sci., v. 68 , n. 3/4, p. $462-$ 472, 2006.

GIMÉNEZ, L.; VENTURINI, N.; KANDRATAVICIUS, N.; HUTTON, M.; LANFRANCONI, A.; RODRÍGUEZ M.; BRUGNOLI, E.; MUNIZ, P. Macrofaunal patterns and animal-sediment relationships in Uruguayan estuaries and coastal lagoons (Atlantic coast of South America). J. Sea Res., v. 87, p. 46-55, 2014.

GRAZEFFEA, V. S.; TALLARICO, L. F.; PINHEIRO, A. S.; KAWANOA, T.; SUZUKIB, M. F.; OKAZAKIB, K.; PEREIRA, C. A.; NAKANO, E. Establishment of the comet assay in the freshwater snail Biomphalaria glabrata (Say, 1818). Mutat. Res., v. 654, n. 1, p. 5863, 2008.

GUERRERO, R. A.; ACHA, E. M.; FRAMINAN, M. B.; LASTA, C. A. Physical oceanography of the Rio de la Plata estuary, Argentina. Cont. Shelf Res., v. 17, p. 727742, 1997.

HUNG, T. C.; MENG, P. J.; HAN, B. C.; CHUANG, A.; HUANG, C. C. Trace metals in different species of mollusca, water and sediments from Taiwan coastal area. Chemosphere, 44, n. 4, p. 833-841, 2001.
HYLAND, J.; BALTHIS, L.; KARAKASSIS, I.; MAGNI, P.; PETROV, A.; SHINE, J.; VESTERGAARD, O.; WARWICK, R. Organic carbon content of sediments as an indicator of stress in the marine benthos. Mar. Ecol. Prog. Ser., v. 295, p. 91-103, 2005.

JHA, A. N. Use of aquatic invertebrates in genotoxicological studies. Mutat. Res., v. 399, n. 1, p. 1-2, 1998.

KENNISH, M. Ecology of estuaries: anthropogenic effects. Marine Science Series. Boca Ratón: CRC Press, 1992.

KOSMEHL, T.; HALlARE, A. V.; BRAUNBECK, T.; HOLLERT, H. DNA damage induced by genotoxicants in zebrafish (Danio rerio) embryos after contact exposure to freeze-dried sediment and sediment extracts from Laguna Lake (The Philippines) as measured by the comet assay. Mutat. Res., v. 650, n. 1, p. 1-14, 2008.

KRISHNA, K. L.; KAISARY, S.; RODRÍGUES, V. Bioaccumulation of some trace metals in the short-neck clam Paphiama labarica from Mandovi estuary Goa. Mar. Pollut. Ecotox., v. 32, p. 229-234, 2006.

LEE, R. F.; STEINERT, S. Use of the single gel electrophoresis/comet assay for detecting DNA damage in aquatic (marine and freshwater) animals. Mutat. Res., v. 544, n. 1, p. 43-64, 2003.

LIVINGSTONE, D. R.; DONKIN, P.; WALKER, C. H. Pollutants in marine ecosystems: an overview. In: WALKER, C. H.; LIVINGSTONE D. R. (Eds.). Persistent Pollutants in Marine Ecosystems. Oxford: Pergamon Press, 1992. p. 236-263.

MACHELLA, N.; BATTINO, M.; PISANELLI, B.; REGOLI, F. Influence of the SCGE Protocol on the Amount of Basal DNA Damage Detected in the Mediterranean Mussel, Mytilus galloprovincialis. Environ. Mol. Mutag., v. 47, p. 579-586, 2006.

MUNIZ, P.; VENTURINI, N.; RODRÍGUEZ, M.; MARTÍNEZ, A.; LAEROT, G.; GÓMEZ, M. Benthic communities in a highly polluted urban bay. In: MILÓN, P. J.; DELGADO, C. T.; PAREDES, L. V.; PAREDES, A. O.; BENAVIDES, F. V. (Eds.). Memorias del IV CLAE: "Ecología y Desarrollo Sostenible: Reto de América Latina para el tercer Milenio". Arequipa, 2000. 274 p.

MUNIZ, P.; VENTURINI, N.; MARTÍNEZ, A. Physicochemical and pollutants of the benthic environment of the Montevideo Coastal Zone, Uruguay. Mar. Pollut. Bull., v. 44, n. 9, p. 962-968, 2002.

MUNIZ, P.; DANULAT, E.; YANNICELLI, B.; GARCÍAALONSO, J.; MEDINA, G.; BÍCEGO, M. C. Assessment of contamination by hydrocarbons and heavy metals in sediments of Montevideo Harbour (Uruguay). Environ. Int., v. 29, n. 8, p. 1019-1028, 2004a.

MUNIZ, P.; VENTURINI, N.; GOMEZ-ERACHE, M. Spatial distribution of chromium and lead in sediments from coastal areas of the Río de la Plata estuary (Montevideo, Uruguay). Braz. J. Biol., v. 64, n. 1, p. 103-116, 2004b.

MUNIZ, P.; VENTURINI, N.; PIRES-VANIN, A. M.; TOMMASI, L. R.; BORJA, A. Testing the applicability of a Marine Biotic Index (AMBI) to assessing the ecological quality of soft-bottom benthic communities, in the South America Atlantic region. Mar. Pollut. Bull., v. 50, n. 6, p. 624-637, 2005. 
MUNIZ, P.; VENTURINI, N.; BURONE, L. Contaminación en la Bahía de Montevideo y zona costera adyacente y su relación con los organismos bentónicos. In: MENAFRA, R.; RODRÍGUEZ, L.; SCARABINO, F.; CONDE, D. (Eds.). Bases para la conservación y manejo de la costa uruguaya. Montevideo: Vida Silvestre, 2006. p. 467-476.

MUNIZ, P.; VENTURINI, N.; HUTTON, M.; KANDRATAVICIUS, N.; PITA, A.; BRUGNOLI, E.; BURONE, L.; GARCÍA-RODRÌGUEZ, F. Ecosystem health of Montevideo coastal zone: A multi approach using some different benthic indicators to improve a ten-year-ago assessment. J. Sea Res., v. 65, n. 1, p. 38-50, 2011.

MUNIZ, P.; HUTTON, M.; KANDRATAVICIUS, N.; LANFRANCONI, A.; BRUGNOLI, E.; VENTURINI, N.; GIMÉNEZ, L. Performance of biotic indices in naturally stressed estuarine environments on the Southwestern Atlantic coast (Uruguay): a multiple scale approach. Ecol. Indic., v. 19, p. 89-97, 2012.

NEWTON, A.; CARRUTHERS, T. J. B.; ICELY, J. The coastal syndromes and hotspots on the coast. Estuar. Coast. Shelf Sci., v. 96, p.39-47, 2012.

NIGRO, M.; FALLENI, A.; DEL BARGA, I.; SCARCELLI, V.; LUCCHESI, P.; REGOLI, F.; FRENZILLI, G. Cellular biomarkers for monitoring estuarine environments: Transplanted versus native mussels. Aquat. Toxicol., v. 77, n. 4, p. 339-347, 2006.

O'CONNOR, W. P. A numerical model of tides and storm surges in the Rio de la Plata estuary. Cont. Shelf Res., v. 11, n. 12, p. 1491-508, 1991.

O'CONNOR, T. P. National distribution of chemical concentrations in mussels and oysters in the USA. Mar. Environ. Res., v. 53, n. 2, p. 117-143, 2002.

RANK, J.; JENSEN, K. Comet assay on gill cells and hemocytes from the blue mussel Mytilus edulis. Ecotoxicol. Environ. Saf., v. 54, n. 3, p. 323- 329, 2003.

RHEE, J. S.; LEE, Y. M.; HWANG, D. S.; WON, E. J.; RAISUDDIN, S.; SHIN, K. H.; LEE, J. S. Molecular cloning, expression, biochemical characteristics, and biomarker potential of theta class glutathione S-transferase (GST-T) from the polychaete Neanthes succinea. Aquat. Toxicol., v. 83, n. 2, p. 104-115, 2007.

RHEE, J. S.; RAISUDDIN, S.; LEE, K. W.; SEO, J. S.; KI, J. S.; KIM, I. C.; PARK, H. G.; LEE JS. Heat shock protein (Hsp) gene response of the intertidal copepod Tigriopus japonicus to environmental toxicants. Comp. Bioch. Physiol. Part C., v. 149 , n. 1, p. 104-112, 2009

ROCHER, B.; LE, GOFF, J.; PELUHET, L.; BRIAND, M.; MANDUZIO, H.; GALLOIS, J.; DEVIER, M.; GEFFARD, O.; GRICOURT, L.; AUGAGNEUR, S.; BUDZINSKI, H.; POTTIER, D.; ANDRÉ, V.; LEBAILLY, P.; CACHOT, J. Genotoxicant accumulation and cellular defence activation in bivalves chronically exposed to waterborne contaminants from the Seine River. Aquat. Toxicol., v. 79, n. 1, p. 65-77, 2006.
SARKAR, A. Assessment of the impact of xenobiotic pollutants on the marine organisms: molecular biomarker approach. In: BHATTACHARYA, B.; GHOSH, A. MAJUMDAR, S. K. (Eds.). Environmental Pollution: Ecological Impacts, Health Issues and Management. Calcutta: Institute of Ecotoxicology and Environmental Sciences and Mudrakar, 2011. p. 70-81.

SARKAR, A.; SINGBAL, S. Y. S.; FONDEKAR, S. P. Pesticide residues in the sediments from the lakes of Schirmacher Oasis, Antarctica. Polar Record., v. 30, p. 3338, 1994.

SARKAR, A.; NAGARAJAN, R.; SINGBAL, S. Y. S.; CHHAPADKAR, S.; PAL, S. Contamination of organochlorine pesticides in sediments from the Arabian Sea along the west coast of India. Wat. Res., v. 31, n. 2, 195-200, 1997.

SARKAR, A.; BHAGAT, J.; SARKER, S. Evaluation of impairment of DNA in marine gastropod, Morula granulata as a biomarker of marine pollution. Ecotoxicol. Environ. Saf., v. 106, p. 253-261, 2014.

STEINERT, S. A. DNA damage as bivalve biomarker and as an environmental assessment tool. Biomarkers, v. 4, p. 492-496, 1999.

STEINERT, S. A.; STERIB-MONTEE, R.; LEATHER, J. M.; CHADWICK D. B. DNA damage in mussels at sites in San Diego Bay. Mutat. Res., v. 399, n.1, p. 65-85, 1998a.

STEINERT, S.; STERIB-MONTEE, R.; SASTRE, M. Influence of sunlight on DNA damage in mussels exposed to polycyclic aromatic hydrocarbons. Mar. Environ. Res., v. 46, n. 1/5, p. $355-358,1998 b$

TRANNUM, H. C.; OLSGARD, F.; SKEI, J. M.; INDREHUS, J.; ØVERÅS, S.; ERIKSEN, J. Effects of copper, cadmium and contaminated harbor sediments on recolonisation of soft bottom communities. J. Exp. Mar. Biol. Ecol., v. 310, n. 1, p. 87-114, 2004.

VENTURINI, N.; BÍCEGO M; TANIGUCHI S; SASAKI S; GARCÍA-RODRÍGUEZ F; BRUGNOLI E; MUNIZ, P.

A multi-molecular marker assessment of organic pollution in shore sediments from the Río de la Plata Estuary, SW Atlantic. Marine Pollution Bulletin, v.: 91 2, p.: 461 475,2015

WALKER, C. H. Organic pollutants: an ecotoxicological perspective, 2nd ed. Boca Raton: CRC Press, 2009. 408 $\mathrm{p}$.

WILSON, J. T.; PASCOE, P. L.; PARRY, J. M.; DIXON, D. R. Evaluation of the comet assay as a method for the detection of DNA damage in the cells of a marine invertebrate, Mytilus edulis L. (Mollusca: Pelecypoda). Mutat. Res., v. 399, n. 1, p. 87-95, 1998.

ZAR, J. Biostatistical Analysis, Fifth Ed. London: Pearson Education, 2010. 944 p. 